\title{
Non-esterified fatty acids are deleterious for human pancreatic islet function at physiological glucose concentration
}

\author{
M. Dubois ${ }^{1}$ J. Kerr-Conte ${ }^{1}$ V. Gmyr ${ }^{1}$ T. Bouckenooghe ${ }^{1} \cdot$ G. Muharram ${ }^{1} \cdot$ M. D'Herbomez ${ }^{2}$ \\ A. Martin-Ponthieu ${ }^{3} \cdot$ M. C. Vantyghem ${ }^{1} \cdot$ B. Vandewalle ${ }^{1} \cdot$ F. Pattou $^{1}$ \\ ${ }^{1}$ ERIT-M 0106 (Diabetes Cell therapy), INSERM, Faculty of Medicine, University of Lille, Lille cedex, France \\ 2 Department of Nuclear Medicine, University Hospital Center of Lille, France \\ ${ }^{3}$ Laboratory of Biochemistry and Molecular Biology, University Hospital Center of Lille, France
}

\begin{abstract}
Aims/hypothesis. Whether excess glucose (glucotoxicity) and excess non-esterified fatty acids (lipotoxicity) act synergistically or separately to alter beta-cell function on Type 2 diabetes remains controversial. We examined the influence of non-esterified fatty acids, with or without concomitant increased glucose concentrations, on human islet function and on the expression of genes involved in lipid metabolism.

Methods. Human islets isolated from non-diabetic and non-obese donors were cultured with 5.5, 16 or $30 \mathrm{mmol} / \mathrm{l}$ glucose, and when appropriate with 1 or $2 \mathrm{mmol} / \mathrm{l}$ non-esterified fatty acids. After $48 \mathrm{~h}$, glucose-stimulated insulin secretion, insulin content, triglyceride content and expression of different genes were evaluated.
\end{abstract}

Results. Non-esterified fatty acids decreased glucosestimulated insulin secretion, insulin content and increased triglyceride content of human isolated islets, independently from the deleterious effect of glucose. In- creased glucose concentrations also decreased glucosestimulated insulin secretion and insulin content, but had no influence on triglyceride content. Glucose-stimulated insulin secretion of islets appeared to be significantly correlated with their triglyceride content. Glucose and non-esterified fatty acids modified the gene expression of carnitine palmitoyltransferase-I, acetyl-CoA carboxylase, acyl-CoA oxidase and uncoupling protein 2.

Conclusion/interpretation. In our model of isolated human islets, increased glucose and non-esterified fatty acids separately reproduced the two major beta-cell alterations observed in vivo, i.e. loss of glucose-stimulated insulin secretion and reduction in islet insulin content. Our results also suggest that this deleterious effect was, at least in part, mediated by modifications in lipid metabolism gene expression. [Diabetologia (2004) 47:463-469]

Keywords Lipotoxicity - Glucotoxicity · Human islets · GSIS · Insulin content · TG content · Gene expression $\cdot$ Lipid metabolism
Received: 21 July 2003 / Revised: 11 December 2003

Published online: 13 February 2004

(C) Springer-Verlag 2004

F. Pattou $(\bowtie)$

ERIT-M 0106 (Diabetes Cell therapy), INSERM,

Faculty of Medicine, University of Lille, 1 place de Verdun,

59045 Lille cedex, France

E-mail: fpattou@univ-lille2.fr

Abbreviations: ACC, Acetyl-CoA carboxylase - ACO, acyl-CoA oxidase $\cdot$ CPT-I, carnitine palmitoyltransferase-I · GSIS, glucose-stimulated insulin secretion - PPAR, peroxisome proliferator-activated receptor - PDX-1, pancreatic/duodenal homeobox-1 - PPRE, peroxisomal proliferator response element $\cdot$ TG, triglyceride $\cdot$ UCP-2, uncoupling protein 2
Progression from normal glucose tolerance to Type 2 diabetes results from a gradual deterioration in beta-cell function, in the presence of insulin resistance [1]. Over the past 10 years, the role of excess glucose in the alteration of beta-cell function has become increasingly clear and has led to the concept of glucotoxicity [2, 3]. At the same time, the deleterious effect of increased NEFA was suggested by studies on Zucker diabetic fatty (ZDF) rats, an animal model of Type 2 diabetes combined with obesity. The authors showed that altered beta-cell function was preceded by an important increase in the plasma concentration of NEFA and subsequent triglyceride (TG) accumulation in pancreatic islets $[4,5]$. This hypothesis, also referred to as lipotoxic- 
ity, was confirmed by in vitro exposure of isolated islets to NEFA $[6,7,8]$. However, whether glucose and NEFA alter beta-cell function synergistically or separately, remains controversial. Some authors have shown that beta-cell failure was induced by increased glucose alone [2,9] or increased NEFA alone [6, 10], while others have suggested that excess glucose or NEFA are not deleterious separately, but synergize in causing glucolipotoxicity [11, 12, 13, 14].

Numerous studies have also shown that glucose and/or NEFA affect the expression of certain genes in islet cells. These include endocrine-specific genes such as insulin, glucagon, somatostatin and the glucose transporter GLUT2 [9, 15, 16, 17, 18]. Glucose and NEFA have also been shown to impair their own intraislet metabolism via changes in expression of genes encoding for key enzymes in glycolytic, lipogenic and fat oxidation pathways $[9,16,19,20,21,22,23,24$, $25,26,27]$. The expression of such transcription factors as pancreatic/duodenal homeobox-1 (PDX-1 or insulin promoter factor-1, IPF-1), peroxisome proliferator-activated receptor (PPAR) $\alpha$ and PPAR $\gamma$, also appear to be modified by glucose and/or NEFA in pancreatic islets $[9,15,16,17,18,25,26,28]$.

To date, most gene expression studies have been conducted in insulin-secreting cell lines or animal tissues. Results concerning beta-cell function and gene expression obtained in these various experimental models are contradictory. In this study, we examined the influence of NEFA on human islet function with or without concomitant increased glucose concentrations. Because lipid metabolism seems to have a crucial role in lipotoxicity [8], we also studied the expression of genes involved in this metabolism.

\section{Materials and methods}

Human tissues and culture conditions. Human pancreata were harvested, in accordance with the Declaration of Helsinki, from brain-dead non-diabetic (mean $\mathrm{HbA}_{1} \mathrm{c}=5.03 \pm 0.09$ ), and non-obese (mean $\mathrm{BMI}=24.2 \pm 1.5$ ) adult donors. Islets were isolated by Liberase (Roche Diagnostics, Meylan, France) digestion using a slightly modified version of Ricordi's automated method [29, 30]. They were then purified using a continuous gradient density of Ficoll Separating Solution (Biochrom AG, Berlin, Germany). Islet preparations were cultured for 12 to 36 h in CMRL-1066 (Gibco BRL, Paisley, Scotland) containing $5.5 \mathrm{mmol} / \mathrm{l}$ glucose and supplemented with $10 \% \mathrm{FCS}$ (Eurobio, Les Ullis, France), $100 \mathrm{UI} / \mathrm{ml}$ penicillin (Eurobio) and $100 \mu \mathrm{g} / \mathrm{ml}$ streptomycin (Eurobio). Islet preparations were then placed in CMRL-1066 medium containing 5.5, 16 or $30 \mathrm{mmol} / \mathrm{l}$ glucose, supplemented with $2 \%$ fatty acid-free BSA (Roche Diagnostics) and when appropriate with 1 or $2 \mathrm{mmol} / \mathrm{l}$ of a mixture of oleate/palmitate (2/1; Sigma Aldrich, Saint Quentin Fallavier, France). NEFA were added to the medium as ethanol solutions. Ethanol was eliminated by evaporation and NEFA were measured to check the concentration (Free Fatty Acid kit, Roche Diagnostics). Control media were supplemented with an equal volume of ethanol and underwent the same evaporation protocol.
Islet TG content. After 48 hours of culture in the different conditions, samples of islet preparations $(n=3)$ containing 1000 islets with an equivalent diameter of $150 \mu \mathrm{mol} / \mathrm{l}$ were sonicated in $\mathrm{NaCl} 0.9 \%$ and $\mathrm{TG}$ content was assessed using the Trinder method (Triglycerides GPO-PAP kit, Roche Diagnostics), without extraction. The TG content was expressed as a ratio over DNA content, measured with the PicoGreen dsDNA Quantification kit (Molecular Probes, Leiden, The Netherlands).

Islet insulin content and secretion. Intracellular insulin content and glucose-stimulated insulin secretion (GSIS) were evaluated after $48 \mathrm{~h}$ of culture in the different conditions, on five distinct islet preparations. For intracellular insulin content, three samples of ten handpicked islets were sonicated in a lysis buffer (Tris $\mathrm{HCl} 10 \mathrm{mmol} / \mathrm{l}$, EDTA $1 \mathrm{mmol} / \mathrm{l}$ ) and insulin was extracted from secretion granules by overnight incubation in an extraction buffer ( $\mathrm{HCl} 0.18 \mathrm{~mol} / \mathrm{l}$ in $95 \%$ ethanol). To assess GSIS, static incubations were done in three batches of ten handpicked islets, for each condition of glucose and NEFA concentration. This step consists of $1 \mathrm{~h}$ preincubation with $2.8 \mathrm{mmol} / \mathrm{l}$ glucose, followed by three incubations of $1 \mathrm{~h}$ with $2.8 \mathrm{mmol} / \mathrm{l}$ glucose (basal 1), $25 \mathrm{mmol} / \mathrm{l}$ glucose (stimulation) and $2.8 \mathrm{mmol} / \mathrm{l}$ glucose (basal 2), respectively, in RPMI medium (Sigma Aldrich) containing 10\% FCS. At the end of each incubation, RPMI was collected. Intracellular and secreted insulin were titered with the bi-insulin IRMA kit (Sanofi Diagnostics Pasteur, Marnes-la-Coquette, France). Insulin was expressed with reference to DNA content. The stimulation index was defined as the ratio of stimulated secretion to the mean of the two basal secretions.

Islet gene expression by quantitative RT-PCR. For each islet preparation $(n=5)$, samples of 2000 to 3000 islets were distributed over the varying conditions. After $48 \mathrm{~h}$ of culture, total RNA was extracted with the Nucleospin RNA II kit (Macherey Nagel, Hoerdt, France) and quantified with the RiboGreen RNA Quantification kit (Molecular Probes). First strand cDNA was synthesised from $1 \mu \mathrm{g}$ RNA using M-MLV (Gibco BRL) primed with random hexamers (Roche Diagnostics), in an equal volume for each islet preparation sample.

The amplification was carried out in a $25 \mu \mathrm{l}$ volume in $1 \mathrm{X}$ SYBR Green PCR Master Mix (Applied Biosystems, Warrington, UK) containing $300 \mathrm{nmol} / \mathrm{l}$ of primers and $3 \mu \mathrm{l}$ cDNA tenfold diluted after reverse transcription. The reaction consisted of $10 \mathrm{~min}$ at $95^{\circ} \mathrm{C}$ for activation of the AmpliTaq Gold DNA Polymerase and 40 cycles including $30 \mathrm{~s}$ denaturation at $95^{\circ} \mathrm{C}$ and $1 \mathrm{~min}$ annealing and extension at $60^{\circ} \mathrm{C}$, and was achieved in the ABI PRISM 7700 Sequence Detection System (Applied Biosystems). Detection of PCR products was monitored at each cycle by measuring the increase in fluorescence caused by the binding of SYBR Green to double strand DNA. The threshold cycle $(\mathrm{Ct})$ reflects the point at which a sufficient number of amplicons have accumulated to be statistically different from the baseline.

Primers were designed using the software Primer Express (Applied Biosystems). For each gene of interest, at least three couples of primers were tested for efficacy. Primers were selected only when their efficacy, calculated as described by the manufacturer, exceeded 95\% (Table 1).

For each gene of interest, samples of islet preparations in each condition were amplified in 96 well plates, concomitantly with specific primers for the gene of interest and for $\beta$-actin and $18 \mathrm{~S}$ as internal standards. As described by the manufacturer, quantification requires the calculation of: (i) the mean $\mathrm{Ct}$ value of the replicate wells for each sample; (ii) the difference between the mean $\mathrm{Ct}$ values of the samples in the gene of in- 
terest wells and those of the internal standards $(\Delta \mathrm{Ct})$; (iii) the difference between the mean $\Delta \mathrm{Ct}$ values of the treated samples and the mean $\Delta \mathrm{Ct}$ value of the non-treated (control) sample $(\Delta \Delta \mathrm{Ct})$

The relative quantitation value is expressed as $2^{-\Delta \Delta C t}$.

Statistical analysis. Results are expressed as means \pm SEM. Statistical analysis was done by using Wilcoxon tests. A $p$ value under 0.05 was considered to indicate significant differences.

\section{Results}

Islet TG content. The presence of $2 \mathrm{mmol} / \mathrm{l}$ NEFA in the culture medium of human islets for $48 \mathrm{~h}$ significantly increased TG content to $81.4 \%, 48.7 \%$ and $101.0 \%$ at $5.5,16$ and $30 \mathrm{mmol} / \mathrm{l}$ glucose, respectively (Fig. 1). The variation of glucose concentration did not influence TG content regardless of NEFA concentration.

GSIS and insulin content of human islets. Addition of 1 or $2 \mathrm{mmol} / \mathrm{l} \mathrm{NEFA}$ to human islets culture medium for $48 \mathrm{~h}$ led to significant $19.3 \%$ and $49.9 \%$ decreases of GSIS, respectively, even at the physiological glucose concentration of $5.5 \mathrm{mmol} / 1$ (Table 2, Fig. 2). Significant reductions were also observed at 16 and $30 \mathrm{mmol} / \mathrm{l}$ glucose. The maximal effect was obtained for $2 \mathrm{mmol} / \mathrm{l} \mathrm{NEFA}$, which totally abolished the islet

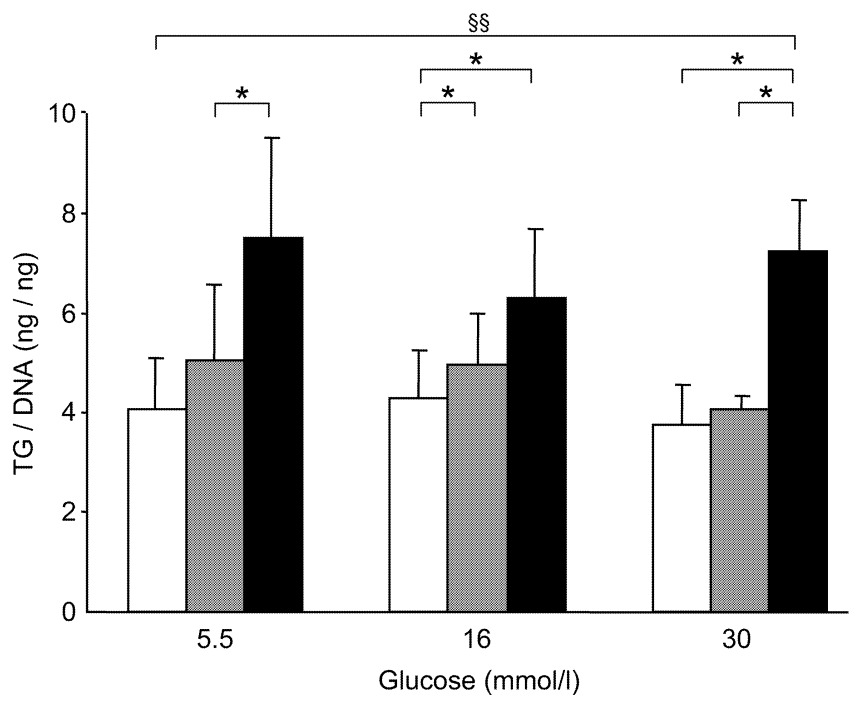

Fig. 1. Islet TG content after $48 \mathrm{~h}$ of culture, with respect to glucose and NEFA concentrations (white bars without NEFA; grey bars $1 \mathrm{mmol} / \mathrm{l} \mathrm{NEFA}$; black bars $2 \mathrm{mmol} / \mathrm{l} \mathrm{NEFA}$ ). $\S \S$ significant effect of glucose and NEFA $(p<0.01), *$ significant effect of NEFA $(p<0.05)$

glucose response (stimulation index dropped to approximately 1). Glucose also reduced the islet stimulation index, in the absence of NEFA or in the presence of $1 \mathrm{mmol} / \mathrm{l} \mathrm{NEFA}$. At the concentration of $30 \mathrm{mmol} / \mathrm{l}$ glucose in the absence of NEFA, GSIS was signifi-

Table 1. Sequences of oligonucleotide primers

\begin{tabular}{|c|c|c|}
\hline Genes & Primers sense & Primers antisense \\
\hline$\beta$-actin & $5^{\prime}$-TTG CCG ACA GGA TGC AGA A-3' & $5^{\prime}$-GCC GAT CCA CAC GGA GTA CT-3' \\
\hline $18 \mathrm{~S}$ & $5^{\prime}$-TCCCA GTAAGTGCGGGTCA-3' & 5'-GATCCGAGGGCCTCACTAAAC-3' \\
\hline Insulin & 5'-GCA GCC TTT GTG AAC CAA CAC-3' & 5'-CCT CGT TCC CCG CAC AC-3' \\
\hline Glucagon & $5^{\prime}$-AGG CCA AGC TGC CAA GG-3' & 5'-TGT CTG CGG CCA AGT TCT TC-3' \\
\hline Glucokinase & $5^{\prime}$-TGG ACA AGC ATC AGA TGA AAC AC-3' & $5^{\prime}$-TCC AGT TGA GAA GGA TGC CC- $3^{\prime}$ \\
\hline GLUT 1 & 5'-GAGGGTTGCTGCAAGCACTC-3' & 5'-TGT CCACGCCATTGTTCTCTT-3' \\
\hline GLUT 3 & 5'-AGC AGATCCTCCAGCGGTT-3' & 5'-AGCTCTAGCACGGTGACTTGC-3' \\
\hline CPT-I & $5^{\prime}$-CTC AAC GCT GAA CAC TCC TGG-3' & $5^{\prime}-\mathrm{CCA}$ TCC TCC GCA TAG CCC-3' \\
\hline $\mathrm{ACC}$ & $5^{\prime}-\mathrm{TGG}$ ACC CAG TCT ACA TCC ACT TG-3' & $5^{\prime}$-TGC ACG GCT ACC TGA TGG T-3' \\
\hline $\mathrm{ACO}$ & $5^{\prime}$-ACA AAG CAG AGG TCC ACG AAT C- $3^{\prime}$ & 5'-TTG CAC ACA GGC GCT TTC T-3' \\
\hline UCP-2 & 5'-ACT GTG CTG AGC TGG TGA CCT-3' & $5^{\prime}$-CCC CAA AGG CAG AAG TGA AG-3' \\
\hline
\end{tabular}

Table 2. Insulin secretion during static incubations, after 48-h exposure to glucose and NEFA

\begin{tabular}{|c|c|c|c|c|c|c|c|c|c|}
\hline & \multicolumn{3}{|c|}{$5.5 \mathrm{mmol} / \mathrm{l}$ Glucose } & \multicolumn{3}{|c|}{$16 \mathrm{mmol} / \mathrm{l}$ Glucose } & \multicolumn{3}{|c|}{$30 \mathrm{mmol} / \mathrm{l} \mathrm{Glucose}$} \\
\hline & $\begin{array}{l}\text { without } \\
\text { NEFA }\end{array}$ & $\begin{array}{l}1 \mathrm{mmol} / \\
1 \mathrm{NEFA}\end{array}$ & $\begin{array}{l}2 \mathrm{mmol} / \\
1 \mathrm{NEFA}\end{array}$ & $\begin{array}{l}\text { without } \\
\text { NEFA }\end{array}$ & $\begin{array}{l}1 \mathrm{mmol} / \\
1 \mathrm{NEFA}\end{array}$ & $\begin{array}{l}2 \mathrm{mmol} / \\
1 \mathrm{NEFA}\end{array}$ & $\begin{array}{l}\text { without } \\
\text { NEFA }\end{array}$ & $\begin{array}{l}1 \mathrm{mmol} / \\
1 \mathrm{NEFA}\end{array}$ & $\begin{array}{l}2 \mathrm{mmol} / \\
1 \mathrm{NEFA}\end{array}$ \\
\hline $\begin{array}{l}\text { Basal } 1 \\
\quad \text { (mUI/ng DNA) }\end{array}$ & $946 \pm 277$ & $1374 \pm 355$ & $1172 \pm 191$ & $942 \pm 207$ & $1231 \pm 262$ & $1275 \pm 223$ & $702 \pm 133$ & $1034 \pm 181$ & $1010 \pm 154$ \\
\hline $\begin{array}{l}\text { Stimulation } \\
\text { (mUI/ng DNA) }\end{array}$ & $1678 \pm 355$ & $2303 \pm 393$ & $1491 \pm 107$ & $1695 \pm 371$ & $1792 \pm 155$ & $1500 \pm 234$ & $688 \pm 137$ & $1127 \pm 68$ & $947 \pm 134$ \\
\hline $\begin{array}{l}\text { Basal } 2 \\
\quad(\mathrm{mUI} / \mathrm{ng} \text { DNA) }\end{array}$ & $589 \pm 79$ & $1153 \pm 171$ & $976 \pm 74$ & $865 \pm 197$ & $1185 \pm 146$ & $1052 \pm 171$ & $767 \pm 152$ & $888 \pm 54$ & $841 \pm 100$ \\
\hline
\end{tabular}




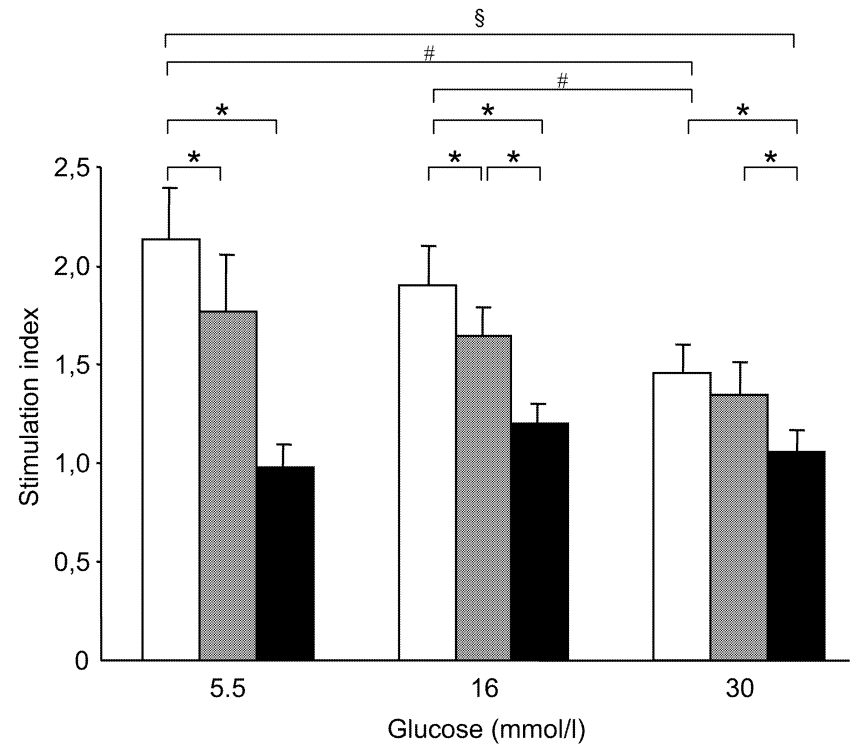

Fig. 2. Stimulation index of islets after $48 \mathrm{~h}$ of culture, with respect to glucose and NEFA concentrations (white bars without NEFA; grey bars $1 \mathrm{mmol} / \mathrm{l} \mathrm{NEFA}$; black bars $2 \mathrm{mmol} / \mathrm{l}$ NEFA). $§$ significant effect of glucose and NEFA $(p<0.05)$, $*$ significant effect of NEFA $(p<0.05)$ and \# significant effect of glucose $(p<0.05)$

cantly lower by $27.9 \%$ and $22.9 \%$ than at 5.5 and $16 \mathrm{mmol} / \mathrm{l}$, respectively. Moreover, effects of NEFA and glucose seemed to be additive, since alteration of GSIS caused by $1 \mathrm{mmol} / \mathrm{l}$ NEFA was more important at 16 and $30 \mathrm{mmol} / \mathrm{l}$ glucose than at $5.5 \mathrm{mmol} / \mathrm{l}$, though the difference was not statistically significant. Finally, a significant inverse correlation appeared between GSIS of islets and their TG content $(r=0.747$; $p=0.018$ ).

The insulin content of human islets cultured with 16 or $30 \mathrm{mmol} / \mathrm{l}$ glucose was significantly lower than with $5.5 \mathrm{mmol} / \mathrm{l}$, since it decreased by $38.7 \%$ and $50.7 \%$, respectively (Fig. 3). Addition of $2 \mathrm{mmol} / \mathrm{l}$ NEFA to the culture medium also reduced insulin content of human islets by $21.0 \%$, in the presence of $5.5 \mathrm{mmol} / \mathrm{l}$ glucose, but had no additional effect at higher glucose concentrations.

Islet gene expression. Modifications in glucose and NEFA concentrations for $48 \mathrm{~h}$ had no influence on insulin, glucagon or glucokinase gene expression in human islets (Fig. 4).

Carnitine palmitoyltransferase-I (CPT-I) expression was increased by NEFA (Fig. 4). Two mmol/l NEFA increased CPT-I expression 2.8-, 3.9- and 5.4-fold, at $5.5,16$ and $30 \mathrm{mmol} / \mathrm{l}$ glucose, respectively. Glucose also influenced CPT-I expression, especially with a concomitant high concentration of NEFA. At $2 \mathrm{mmol} / \mathrm{l} \mathrm{NEFA}$, glucose increased CPT-I expression 1.7- and 2.1-fold at 16 and $30 \mathrm{mmol} / \mathrm{l}$ glucose, respectively. However this induction was not significant.

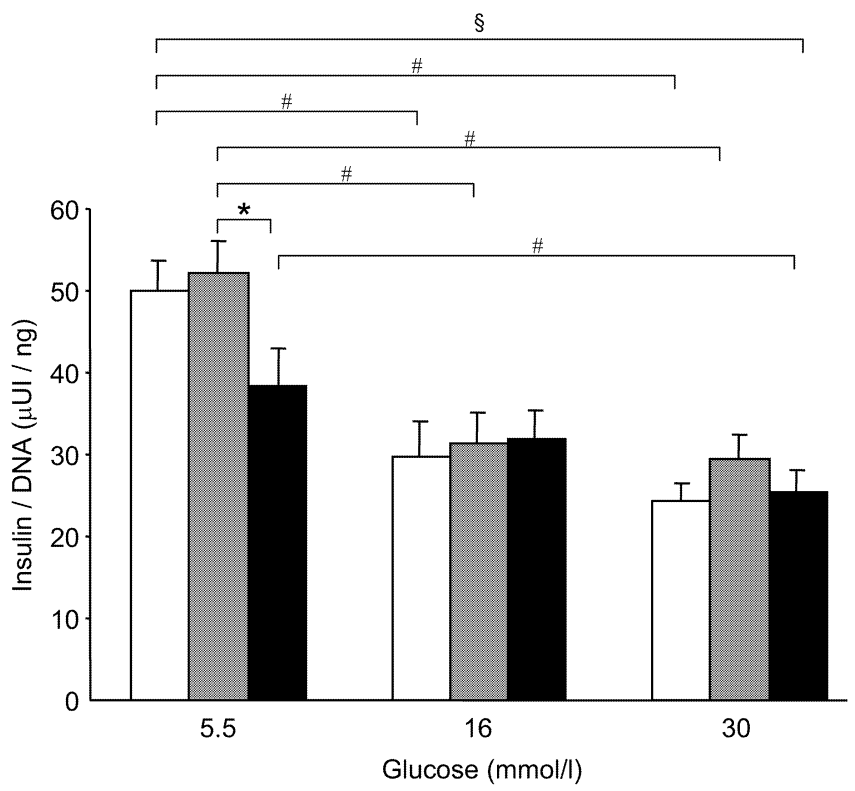

Fig. 3. Insulin content of islets after 48 h of culture, with respect to glucose and NEFA concentrations (white bars without NEFA; grey bars $1 \mathrm{mmol} / \mathrm{l} \mathrm{NEFA}$; black bars $2 \mathrm{mmol} / \mathrm{l}$ NEFA). $\S$ significant effect of glucose and NEFA $(p<0.05)$, * significant effect of NEFA $(p<0.05)$ and \# significant effect of glucose $(p<0.05)$

CPT-I expression was inversely correlated with GSIS $(r=0.702 ; p=0.033)$ and correlated with TG content of islets $(r=0.750 ; p=0.017)$.

The most noteworthy variation concerning acetylCoA carboxylase (ACC) was observed with the combination of $30 \mathrm{mmol} / \mathrm{l}$ glucose and $2 \mathrm{mmol} / \mathrm{l} \mathrm{NEFA}$, which increased ACC gene expression 1.7-fold, compared with $5.5 \mathrm{mmol} / \mathrm{l}$ glucose and no NEFA (Fig. 4). Note, however, that ACC expression also increased with $16 \mathrm{mmol} / \mathrm{l}$ glucose and no NEFA, since it was 1.4-fold the level of ACC expression with $5.5 \mathrm{mmol} / \mathrm{l}$ glucose.

GLUT3, acyl-CoA oxidase (ACO) and uncoupling protein 2 (UCP-2) gene expression were similarly regulated by glucose and NEFA (Fig. 4). The expression of these five genes increased with glucose concentration, in the absence of NEFA. Conversely, 1 and $2 \mathrm{mmol} / \mathrm{l}$ NEFA decreased their expression when combined with high glucose concentrations (16 and $30 \mathrm{mmol} / \mathrm{l})$.

In contrast to GLUT3, GLUT1 expression was increased by NEFA at 16 and $30 \mathrm{mmol} / \mathrm{l}$ glucose (Fig. 4).

\section{Discussion}

Type 2 diabetes results from the failure of beta-cells to compensate for increased insulin secretory demand [1]. Increased glucose and NEFA seem to actively contribute to beta-cell function alteration, and their 
Insulin
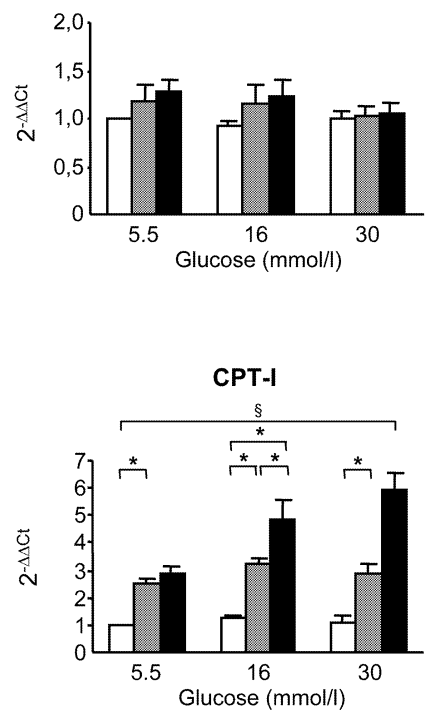

GLUT 1

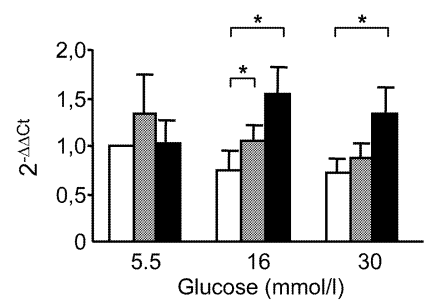

Glucagon
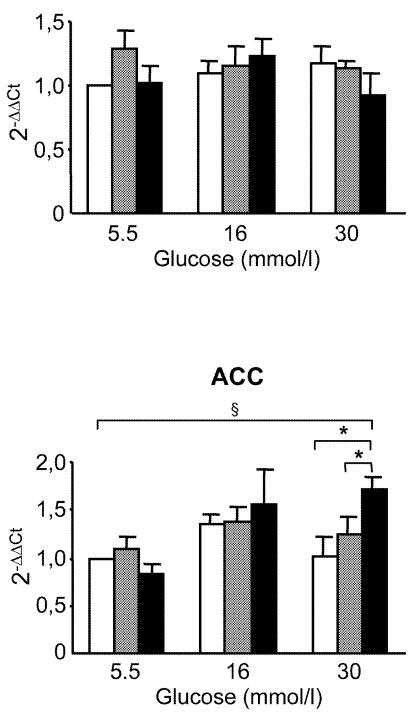

GLUT 3

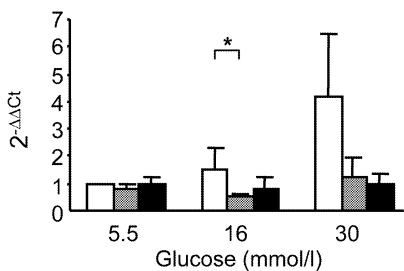

Glucokinase

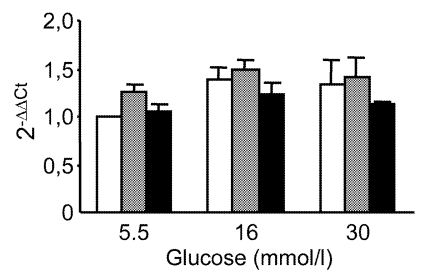

ACO

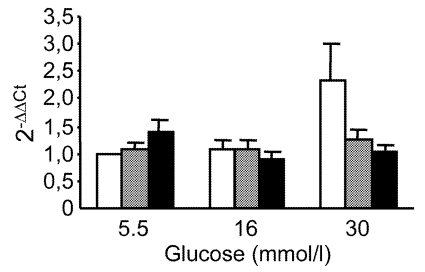

UCP-2

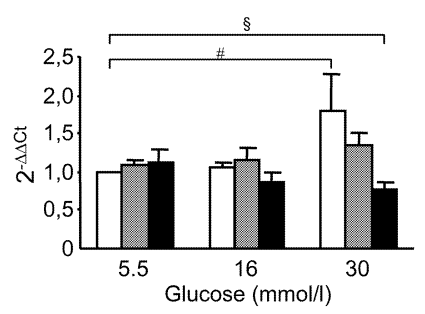

Fig. 4. Gene expression after $48 \mathrm{~h}$ of culture, with respect to glucose and NEFA concentrations (white bars without NEFA; grey bars $1 \mathrm{mmol} / \mathrm{l} \mathrm{NEFA;} \mathrm{black} \mathrm{bars} 2 \mathrm{mmol} / \mathrm{l} \mathrm{NEFA).} \S$ significant effect of glucose and NEFA $(p<0.05)$, * significant effect of NEFA $(p<0.05)$ and \# significant effect of glucose $(p<0.05)$

action is, at least in part, mediated by modifications in gene expression [9, 17]. We studied the respective influence of glucose and NEFA on human islet function and several gene expressions. Both increased glucose and NEFA separately mimicked the two major betacell alterations observed in vivo, i.e., loss of GSIS and reduction in islet insulin content. The effects of glucose and NEFA were also partially additive. Functional alterations were associated with intracellular accumulation of TG and modifications of certain islet gene expressions.

In vivo, the normal plasma concentration of NEFA is less than $0.6 \mathrm{mmol} / \mathrm{l}$, but could exceed $1 \mathrm{mmol} / \mathrm{l}$ in Type 2 diabetic patients [31,32]. Palmitate and oleate are the two most represented NEFA in plasma (20 to $25 \%$ each) and circulate linked to albumin. To mimic what is observed in vivo, we used a mixture of oleate and palmitate with $2 \%$ fatty acid-free BSA. This high albumin concentration was used to obtain an appropriate albumin to NEFA ratio. It is indeed important to note that the effect of NEFA on beta-cells can differ with NEFA subtypes: it was suggested that saturated NEFA, such as palmitate, impaired beta-cell function and viability whereas monounsaturated NEFA, such as oleate, can prevent this deleterious effect [33, 34]. Using a mixture of oleate and palmitate, our model did not distinguish the effect of each NEFA subtype, but tended to reproduce the plasmatic mixture of NEFA that exists in vivo. This methodological difference could explain some of the discrepancies between our results on gene expression and others, which in most cases used palmitate alone.

With our model of in-vitro human islets, we showed that beta-cell alterations characteristic of clinical Type 2 diabetes, including loss of GSIS and decrease in insulin content, can be reproduced with either increased glucose or NEFA concentrations. The deleterious effect of high glucose is well established $[2,3]$, but increased NEFA at physiological glucose concentrations were also able to significantly alter GSIS and insulin content. These results are in accordance with previous studies [6, 10, 33], but argue against the hypothesis that increased glucose is a prerequisite for the deleterious effect of NEFA on betacell function $[11,12,13,14]$. We also found that in- 
creased glucose and NEFA have additive effects since their combination led to more pronounced deterioration of beta-cell function.

Increased NEFA concentrations induced constant decrease in GSIS but inconstant decrease in insulin content, and had no influence on insulin gene expression, as described in certain studies [35], in contrast to others [17, 18]. Those results suggested that NEFA could probably act via pathways not related to betacell exhaustion, by inducing for example overexpression of hormone-sensitive lipase [36] or change in signal recognition not yet clearly understood [37].

In accordance with these studies, increased NEFA induced TG accumulation in islets, which was inversely correlated with GSIS. As shown previously [38], a chronic increase in fatty acids, enhances insulin basal secretion (hence diminushing GSIS) by stimulating fatty acyl-CoA that acts distally and in turn stimulates the exocytic machinery. In accordance with previous studies, NEFA concentrations appeared also linked to CPT-I expression in human islets, [22, 35]. CPT-I's involvement in fatty acid penetration into the mitochondria [39], plays a central role in the repartition of fatty acids between mitochondrial oxidation and their accumulation as long chain fatty acyl-CoA or complex lipids in the cytoplasm. The marked increase in CPT-I expression induced by NEFA, and its negative correlation with GSIS suggest that CPT-I could exert a central role in the loss of beta-cell signal recognition induced by NEFA. Those results are concordant with the glucose fatty acid cycle reported in rat islets $[6,7,10]$. This hypothesis proposes that an increase in NEFA oxidation leads to a decrease in glucose metabolism in beta-cells, according to the Randle cycle observed in other tissues [40]. The consequence is a reduction in insulin secretion, since it is linked to glucose oxidation. This hypothesis is supported by (i) the restoration of insulin secretion by inhibition of NEFA oxidation and (ii) the specificity of the altered response to glucose, as opposed to other secretagogues $[6,7,10]$. We report, however, that the concomitant presence of increased glucose and NEFA also induced ACC gene expression in islets. ACC induces the inhibitor of CPT-I, malonyl-CoA, and is also critical for the regulation of fatty-acid balance between oxidation and cytoplasmic accumulation. At this time, the effect of NEFA on ACC expression is still controversial $[20,35,38,41]$. So, complementary studies exploring enzymatic activity of CPT-I and NEFA oxidation are necessary to determine the precise interaction between CPT-I and ACC and their regulation by glucose and NEFA.

In conclusion, we found in our model of isolated human islets that exposure to increased glucose or to a mixture of palmitate and oleate independently reproduced some of the islet anomalies observed in Type 2 diabetes in vivo, i.e. loss of GSIS, decrease in islet insulin content and islet TG accumulation. Our results also suggested that this deleterious effect was, at least in part, mediated by modifications in the expression of genes implicated in lipid metabolism.

Acknowledgements. The authors are most grateful to A. Ktorza for critical review of the manuscript, to C. Dacquet for scientific comments, to F. Zerimech for engineering in lipids dosage, to L. Touzet for language review and to S. Bélaïch, G. Grard, L. George, N. Houriez, C. Chabrol and V. Avellaneda for technical expertise. This study was supported by a grant from the French Ministry of Research and the International Research Institute SERVIER (Action Concertée 2002 "Molécules et Cibles Thérapeutiques"), and doctoral stipends from the Conseil Régional Nord-Pas-de-Calais, the University Hospital Centre of Lille and the French National Academy of Medicine.

\section{References}

1. Kahn SE (2000) The importance of the beta-cell in the pathogenesis of type 2 diabetes mellitus. Am J Med 108 [Suppl 6a]:2S-8S

2. Eizirik DL, Korbutt GS, Hellerstrom C (1992) Prolonged exposure of human pancreatic islets to high glucose concentrations in vitro impairs the beta-cell function. J Clin Invest 90:1263-1268

3. Marshak S, Leibowitz G, Bertuzzi et al. (1999) Impaired bcell functions induced by chronic exposure of cultured human pancreatic islets to high glucose. Diabetes 48:1230-1236

4. Lee Y, Hirose H, Ohneda M, Johnson JH, McGarry JD, Unger RH (1994) Beta-cell lipotoxicity in the pathogenesis of non-insulin-dependent diabetes mellitus of obese rats: impairment in adipocyte-beta-cell relationships. Proc Natl Acad Sci USA 91:10878-10882

5. Lee Y, Hirose H, Zhou YT, Esser V, McGarry JD, Unger RH (1997) Increased lipogenic capacity of the islets of obese rats: a role in the pathogenesis of NIDDM. Diabetes 46:408-413

6. Elks ML (1993) Chronic perifusion of rat islets with palmitate suppress glucose-stimulated insulin release. Endocrinology 133:208-214

7. Zhou YP, Grill VE (1994) Long-term exposure of rat pancreatic islets to fatty acids inhibits glucose-induced insulin secretion and biosynthesis through a glucose fatty acid cycle. J Clin Invest 93:870-876

8. Segall L, Lameloise N, Assimacopoulos-Jeannet F et al. (1999) Lipid rather than glucose metabolism is implicated in altered insulin secretion caused by oleate in INS-1 cells. Am J Physiol 277:E521-E528

9. Jonas JC, Sharma A, Hasenkamp et al. (1999) Chronic hyperglycemia triggers loss of pancreatic beta cell differentiation in an animal model of diabetes. J Biol Chem 274: 14112-14121

10. Sako Y, Grill VE (1990) A 48-hour lipid infusion in the rat time-dependently inhibits glucose-induced insulin secretion and b cell oxidation through a process likely coupled to fatty acid oxidation. Endocrinology 127:1580-1589

11. Jacqueminet S, Briaud I, Rouault C, Reach G, Poitout V (2000) Inhibition of insulin gene expression by long-term exposure of pancreatic beta cells to palmitate is dependent on the presence of a stimulatory glucose concentration. Metabolism 49:532-536

12. Briaud I, Harmon JS, Kelpe CL, Segu VB, Poitout V (2001) Lipotoxicity of the pancreatic beta-cell is associated with glucose-dependent esterification of fatty acids into neutral lipids. Diabetes 50:315-321 
13. Harmon JS, Gleason CE, Tanaka Y, Poitout V, Robertson RP (2001) Antecedent hyperglycemia, not hyperlipidemia, is associated with increased islet triacylglycerol content and decreased insulin gene mRNA level in Zucker diabetic fatty rats. Diabetes 50:2481-2486

14. Briaud I, Kelpe CL, Johnson LM, Tran PO, Poitout V (2002) Differential effects of hyperlipidemia on insulin secretion in islets of langerhans from hyperglycemic versus normoglycemic rats. Diabetes 51:662-668

15. Sharma A, Olson LK, Robertson RP, Stein R (1995) The reduction of insulin gene transcription in HIT-T15 beta cells chronically exposed to high glucose concentration is associated with the loss of RIPE3b1 and STF-1 transcription factor expression. Mol Endocrinol 9:1127-1134

16. Laybutt DR, Sharma A, Sgroi DC, Gaudet J, Bonner-Weir S, Weir GC (2002) Genetic regulation of metabolic pathways in beta-cells disrupted by hyperglycemia. J Biol Chem 277:10912-10921

17. Gremlich S, Bonny C, Waeber G, Thorens B (1997) Fatty acids decrease IDX-1 expression in rat pancreatic islets and reduce GLUT2, glucokinase, insulin, and somatostatin levels. J Biol Chem 272:30261-30269

18. Yoshikawa H, Tajiri Y, Sako Y, Hashimoto T, Umeda F, Nawata H (2001) Effects of free fatty acids on beta-cell functions: a possible involvement of peroxisome proliferator-activated receptors alpha or pancreatic/duodenal homeobox. Metabolism 50:613-618

19. Brun T, Roche E, Kim KH, Prentki M (1993) Glucose regulates acetyl-CoA carboxylase gene expression in a pancreatic beta-cell line (INS-1). J Biol Chem 268:18905-18911

20. Brun T, Assimacopoulos-Jeannet F, Corkey BE, Prentki M (1997) Long-chain fatty acids inhibits acetyl-CoA carboxylase gene expression in the pancreatic beta-cell line INS1. Diabetes 46:393-400

21. Roche E, Assimacopoulos-Jeannet F, Witters LA et al. (1997) Induction by glucose of genes coding for glycolytic enzymes in a pancreatic beta-cell line (INS-1). J Biol Chem 272:3091-3098

22. Assimacopoulos-Jeannet F, Thumelin S, Roche E, Esser V, McGarry JD, Prentki M (1997) Fatty acids rapidly induce the carnitine palmitoyltransferase I gene in the pancreatic b-cell line INS-1. J Biol Chem 272:1659-1664

23. Bollheimer LC, Skelly RH, Chester MW, McGarry JD, Rhodes CJ (1998) Chronic exposure to free fatty acid reduces pancreatic beta cell insulin content by increasing basal insulin secretion that is not compensated for by a corresponding increase in proinsulin biosynthesis translation. $\mathrm{J}$ Clin Invest 101:1094-1101

24. Roche E, Farfari S, Witters LA et al. (1998) Long-term exposure of beta-INS cells to high glucose concentrations increases anaplerosis, lipogenesis, and lipogenic gene expression. Diabetes 47:1086-1094

25. Zhou YT, Shimabukuro M, Wang MY et al. (1998) Role of peroxisome proliferator-activated receptor alpha in disease of pancreatic beta cells. Proc Natl Acad Sci USA 95:88988903

26. Roduit R, Morin J, Masse F et al. (2000) Glucose downregulates the expression of the peroxisome proliferator-ac- tivated receptor-alpha gene in the pancreatic beta-cell. J Biol Chem 275:35799-35806

27. Lameloise N, Muzzin P, Prentki M, AssimacopoulosJeannet F (2001) Uncoupling protein 2: a possible link between fatty acid excess and impaired glucose-induced insulin secretion? Diabetes 50:803-809

28. Buteau J, Roduit R, Susini S, Prentki M (1999) Glucagonlike peptide-1 promotes DNA synthesis, activates phosphatidylinositol 3-kinase and increases transcription factor panceatic and duodenal homeobox gene 1 (PDX-1) DNA binding activity in beta (INS-1)-cells. Diabetologia 42: $856-864$

29. Ricordi C, Lacy PE, Finke EH, Olack BJ, Scharp DW (1988) Automated method for isolation of human pancreatic islets. Diabetes 37:413-420

30. Shapiro AMJ, Lakey JRT, Ryan EA et al. (2000) Islet transplantation in seven patients with type 1 diabetes mellitus using a glucocorticoid-free immunosuppressive regimen. New England J Med 343:230-238

31. Reaven GM, Hollenbeck C, Jeng CY, Wu MS, Chen YD (1988) Measurement of plasma glucose, free fatty acid, lactate, and insulin for $24 \mathrm{~h}$ in patients with NIDDM. Diabetes 37:1020-1024

32. McGarry JD (1992) What if Minkowski had been ageusic? An alternative angle on diabetes. Science 258:766-770

33. Maedler K, Oberholzer J, Bucher P, Spinas GA, Donath MY (2003) Monounsaturated fatty acids prevent the deleterious effects of palmitate and high glucose on human pancreatic beta-cell turnover and function. Diabetes 52:726733

34. El-Assaad W, Buteau J, Peyot ML et al. (2003) Saturated fatty acids synergize with elevated glucose to cause pancreatic beta-cell death. Endocrinology 144:4154-4163

35. Busch AK, Cordery D, Denyer GS, Biden TJ (2002) Expression profiling of palmitate- and oleate-regulated genes provides novel insights into the effects of chronic lipid exposure on pancreatic beta-cell function. Diabetes 51:977987

36. Winzell MS, Svensson H, Enerback S et al. (2003) Pancreatic beta-cell lipotoxicity induced by overexpression of hormone-sensitive lipase. Diabetes 52:2057-2065

37. Louet JF, Chatelain F, Decaux JF et al. (2001) Long-chain fatty acids regulate liver carnitine palmitoyltransferase I gene (L-CPT I) expression through a peroxisome-proliferator-activated receptor alpha (PPARalpha)-independent pathway. Biochem J 354:189-197

38. Yaney GC, Corkey BE (2003) Fatty acid metabolism and insulin secretion in pancreatic beta cells. Diabetologia 46:1297-1312

39. McGarry JD, Woeltje KF, Schroeder JG, Cox WF, Foster DW (1990) Carnitine palmitoyltransferase-structure/function/regulatory relationships. Prog Clin Biol Res 321:193208

40. Randle PJ (1998) Regulatory interactions between lipids and carbohydrates: the glucose fatty acid cycle after 35 years. Diabetes Metab Rev 14:263-283

41. Duplus E, Glorian M, Forest C (2000) Fatty acid regulation of gene transcription. J Biol Chem 275:30749-30752 